Pesq. Vet. Bras. 36(6):551-558, junho 2016 DOI: $10.1590 / \mathrm{S} 0100-736 \mathrm{X} 2016000600015$

\title{
Electrocardiographic parameters of the American Miniature Horse: influence of age and sex ${ }^{1}$
}

\author{
Bianca P. Santarosa ${ }^{2}$, Maria L.G. Lourenço ${ }^{2 *}$, Gabriela N. Dantas², Carla M.V. Ulian², \\ Marta C.T. Heckler ${ }^{2}$, Mateus J. Sudano ${ }^{3}$, Roberto C. Gonçalves ${ }^{2}$ \\ and Simone B. Chiacchio ${ }^{2}$
}

\begin{abstract}
Santarosa B.P., Lourenço M.L.G., Dantas G.N., Ulian C.M.V., Heckler M.C.T., Sudano M.J., Gonçalves R.C. \& Chiacchio S.B. 2016. Electrocardiographic parameters of the American Miniature Horse: influence of age and sex. Pesquisa Veterinária Brasileira 36(6):551-558. Departamento de Clínica Veterinária, Faculdade de Medicina Veterinária e Zootecnia, Universidade Estadual Paulista, Campus de Botucatu, Distrito de Rubião Júnior s/n, Botucatu, SP 18618-970, Brazil. E-mail: mege@fmvz.unesp.br

The veterinary cardiology has growing importance in equine medicine. There are studies of standardization of electrocardiographic parameters of many races, according to their stature and ability. However, no studies are in the literature with the American Miniature Horse. To evaluate the electrocardiogram (ECG) tracing configuration of this breed at rest and to verify the influence of age and sex on ECG parameters, 203 horses including 143 females and 60 males were divided into four age groups (foals, yearlings, adults and elderly). Electrocardiographic parameters were performed by computerized electrocardiogram (TEB), and the parameters were evaluated in six leads of frontal plane (Lead I, II, III, $\mathrm{aVR}, \mathrm{aVL}$ and $\mathrm{aVF}$ ) and base-apex (BA). Heart rates (HR) decreased with increasing age were higher in males than in females. Sinus tachycardia followed by sinus arrhythmia was dominant in both sexes. The cardiac axis was higher in males and ranged between $120^{\circ}$ and $150^{\circ}$ for foals, $30^{\circ}$ and $60^{\circ}$ for yearlings and adults, and $60^{\circ}$ and $90^{\circ}$ for the elderly. The $\mathrm{P}$ wave was bifid in several animals. The P-wave amplitude and T-wave duration from lead II and BA were larger in males than in females. The majority of the animals exhibited ST segment depression and a negative T-wave. The most common QRS complex morphology was Qr. Differences were observed between the electrocardiographic tracings of males and females, and age influenced the ECG parameters. Therefore, this study established the ECG patterns for the American Miniature Horse breed and could be used to determine the influence of age and sex on several of the studied variables.
\end{abstract}

INDEX TERMS: Equine, electrocardiogram, ponies, age, sex.

RESUMO.- [Parâmetros eletrocardiográficos de equinos Mini Horse: influência da idade e sexo.] A cardiologia veterinária possui crescente importância na medicina equina. Existem estudos de padronização dos parâmetros eletrocardiográficos de muitas raças, de acordo com sua estatura e aptidão. No entanto, não há na literatura traba-

\footnotetext{
${ }^{1}$ Received on August 28, 2015.

Accepted for publication on April 6, 2016.

${ }^{2}$ Faculdade de Medicina Veterinária e Zootecnia, Universidade Estadual Paulista (Unesp), Rubião Jr s/n., Botucatu, SP 18618-970, Brazil. *Corresponding author: mege@fmvz.unesp.br

${ }^{3}$ Laboratório de Genética e Zootecnia, Faculade de Medicia Veterinária, Universidade Federal do Pampa (Unipampa), Av. General Osório 900, Bagé, Uruguaiana, RS 96400-100, Brazil.
}

lhos com os equinos da raça Miniature Horse. Os objetivos deste trabalho foram avaliar a configuração do traçado do eletrocardiograma (ECG) em repouso, de equinos desta raça, além de verificar a influência do sexo e da idade sobre os parâmetros eletrocardiográficos desses animais. Foram utilizados 203 equinos desta raça, hígidos, sendo 143 fêmeas e 60 machos, classificados em quatro faixas etárias (potros, sobreanos, adultos e idosos). Os exames eletrocardiográficos foram realizados por eletrocardiograma computadorizado (TEB), e os parâmetros foram avaliados em seis derivações do plano frontal (DI, DII, DIII, aVR, aVL e $\mathrm{aVF}$ ) e base-ápice (BA). A frequência cardíaca (FC) diminuiu com a progressão da idade, e foi maior nos machos do que nas fêmeas. 0 ritmo mais comum em ambos os se- 
xos foi taquicardia sinusal, seguido de arritmia sinusal. 0 eixo cardíaco foi maior nos machos do que nas fêmeas, e nos potros ficou entre 120 e $150^{\circ}$, nos sobreano e adultos permaneceu entre 30 e $60^{\circ}$, e nos idosos entre 60 e $90^{\circ}$. A amplitude da onda $\mathrm{P}$ e a duração da onda $\mathrm{T}$ foram maiores nos machos do que nas fêmeas na DII e BA. A maioria dos animais apresentou segmento ST infradesnivelado e onda T negativa. A morfologia do complexo QRS mais encontrada em todos os casos foi Qr. Este estudo permitiu estabelecer os padrões eletrocardiográficos para a raça Mini Horse e conseguiu verificar a influência da progressão da idade nas diversas variáveis estudadas, bem como a diferença entre os sexos.

TERMOS DE INDEXAÇÃO: Eletrocardiograma, equinos, pôneis, faixa etária, sexo.

\section{INTRODUCTION}

In recent decades, the use of veterinary cardiology has become significant in equine medicine by providing early diagnosis and treatment of diseases and establishing prognoses related to the athletic performance of horses (Diniz et al. 2011, Pedersen et al. 2013).

In addition to a careful clinical examination of the cardiovascular system, an electrocardiogram (ECG) is an important part for a complete cardiac evaluation because it recognises disorders in the formation and conduction of cardiac impulses; moreover, ECGs can be used to diagnose various arrhythmias and evaluate the evolution of certain cardiac diseases (White and Rhode 1974, Diniz et al. 2008). An ECG is a complementary, non-invasive, low-cost exam that is easily performed in the field (Fregin 1982, Lessa et al. 2012).

According to Hilwig (1977) and Illera et al. (1987), ECG parameters differ among horse breeds, and thus specific patterns must be identified for each breed. The orientation, amplitude and duration of ECG waves depend on several factors in addition to the specific breed, including age, sex and the lead being examined (Robertson 1992, Ayala et al. 1995, Fernandes et al. 2004).

Standard ECG patterns and the associations of these patterns with specific types of athletic activity have been described for several types of horses, including Mangalarga Marchador (Diniz et al. 2008), classic riding horses (Diniz et al. 2011), English Thoroughbred (Fernandes et al. 2004), Lusitano (Melchert et al. 2012), Andaluz (Ayala et al. 1995, Ayala et al. 1998, Ayala et al. 2000), Quarter Horses (Mantovani et al. 2013, Palma et al. 2013), ponies (Buss et al. 1975, Lombard et al. 1984, Rezakhani et al. 2010), Arabian (Yonezawa et al. 2009, Dumont et al. 2010, Dumont et al. 2011) and crossbred polo horses (Bello et al. 2012). However, the ECG patterns of the American Miniature Horse breed have not been studied.

American Miniature Horses have the conformation of a horse in miniature and are proportionally muscular according to the Brazilian Association of Breeders of Miniature Horses (2013). American Miniature Horses are used as pets and for riding and pulling. The major unique features of this breed include their suitability for housing in small spaces, low breeding costs, miniature size, strength, docility and rusticity. These characteristics have led to increased popularity and numbers of the breed in Brazil. Although the American Miniature Horse has the basic conformation of a horse, differences in the conformation characteristics of this breed compared to large breeds are observed. Organic adaptations occur over time, and cardiovascular functioning might vary according to the characteristics and functions of different breeds. Therefore, this study aimed to describe the ECG parameters of the American Miniature Horse breed and verify the hypothesis that age and gender influence in these parameters.

\section{MATERIALS AND METHODS}

Ethical considerations. This project had the approval of the Ethics Committee on Animal Use - CEUA (n. 094/2012 CEUA), and the owner of the farm gave informed consent.

Animals.A total of 203 American Miniature Horses were evaluated, including 143 females (70.45\%) and 60 males (29.55\%). The animals were from four different farms in the Botucatu City region. The horses were between 15 days and 21 years old and weighed between 10 to $190 \mathrm{~kg}$, with an average of $116.95 \pm 33.62 \mathrm{~kg}$. All the horses were weighed indirectly with a weight tape.

The animals were classified by age. There were 17 foals (15 days to 10 months, 11 males and six females), 68 yearlings (1-3 years, 27 males and 41 females), 70 adults (4-9 years, 16 males and 54 females) and 48 elderly horses (10-21 years, 6 males and 42 females).

Clinical examination. Before beginning the study, the animals were subjected to a clinical examination consisting of a general physical examination (evaluation of the apparent mucosa, hydration degree, and capillary refill time; lymph node and arterial pulse palpation; cardiac and respiratory frequency measurements; intestinal motility and ileocecal valve discharge evaluation; and rectal temperature measurement) and an animal history evaluation (current clinical signs and previous diseases). The exclusion criterion for this study was the presence of altered cardiac auscultation presenting as a cardiac murmur or arrhythmia.

Electrocardiographic examination. For ECG, a computerised device (ECG Acquisition Module PC-ECG, version 2.0. Tecnologia Eletrônica Brasileira (TEB), Ltd., São Paulo/SP, Brazil) was used. The recording was performed with the animals haltered in an area with floor plates coated in rubber. The animals remained standing and stationary with their limbs parallel without sedation, tranquilisation or anaesthetisation. The ECG tracing was performed sequentially on each horse from leads in the frontal plane (I, II, III, aVR, aVL and aVF), with the electrodes positioned according to Fig. $1 \mathrm{~A}$.

The distribution of electrodes for the bipolar BA lead system was as described by Patteson (1996) and is illustrated in Figure $1 \mathrm{~B}$.

The tests were performed at a speed of $50 \mathrm{~mm} /$ second, and the sensitivity was set to $1 \mathrm{~cm}=1$ millivolt $(\mathrm{mV})$ over 1 minute. At least 10 complexes were analysed on each ECG (Fig.2). The heart rate, morphology and duration (seconds) of the $\mathrm{P}$, and $\mathrm{T}$ waves; the QRS complex; and the PR and QT intervals were analysed for each ECG exam recorded. Measurements of the P, R, T and S wave amplitudes (mV); ST segment (normal, depression and elevation); and $\mathrm{T}$ wave polarity (positive, negative or biphasic) were obtained from all seven leads. The mean cardiac electrical axis, as expressed in degrees, was obtained from leads I and III. 

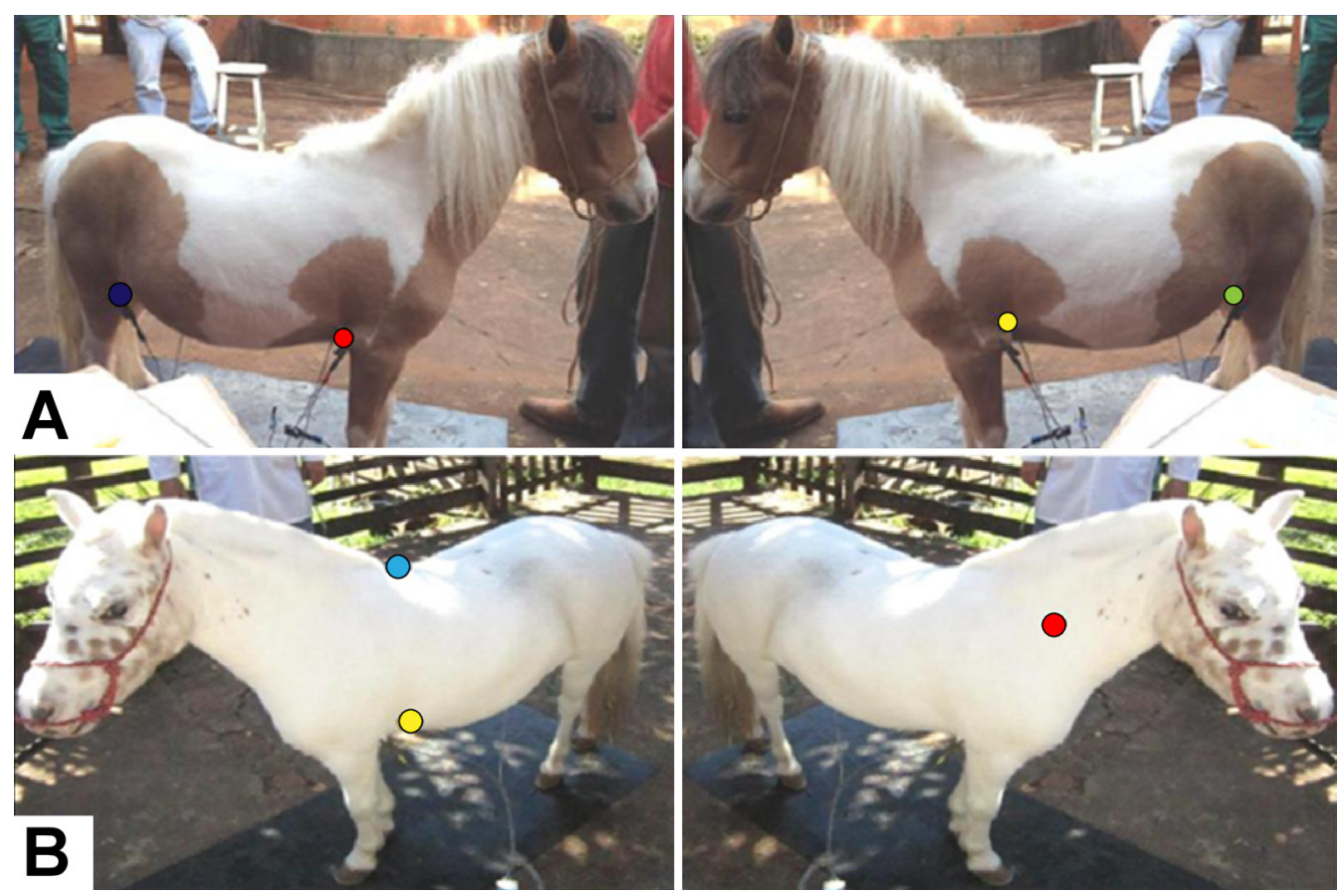

Fig.1. The placement of electrodes on an American Miniature Horse to record the electrocardiogram from the leads. (A) The placement of the electrodes to record from the six leads of the frontal plane (I, II, III, aVF, aVL, and aVF) for the electrocardiographic exam. The right and left thoracic electrodes were positioned above the olecranon, and the right and left pelvic electrodes were positioned above the patellar ligaments in the cranial face of each limb. (B) The placement of electrodes to record from the BA lead for the electrocardiographic exam. The yellow electrode was positioned on the left side above the cardiac apex immediately behind the olecranon. The red electrode was positioned on the right side cranial to the scapula and near the jugular vein, and the ground electrode was attached to the withers.

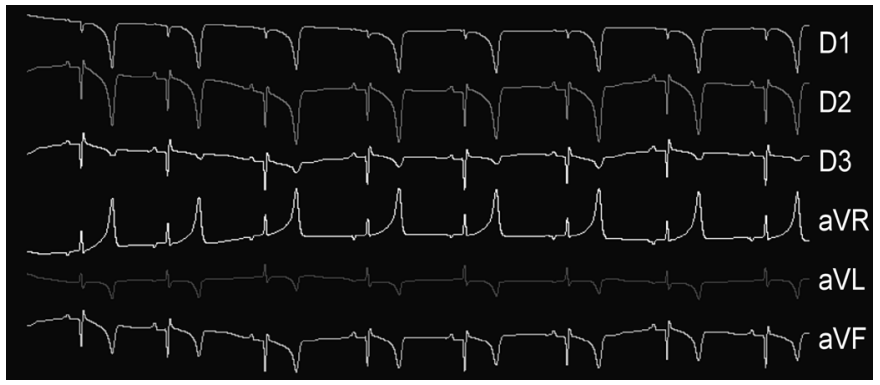

Fig.2. Electrocardiographic tracing of an American Miniature Horse from six leads of the frontal plane.

Statistical analysis. The effects of sex and age on the cardiac parameters from the seven leads were evaluated. For the statistical analysis, the dependent variables were the cardiac parameters HR; the P and T wave duration; the PR, QT and QRS complex interval duration in seconds; the $\mathrm{P}, \mathrm{R}, \mathrm{S}$ and $\mathrm{T}$ wave amplitude in millivolts; and the axis in degrees were analysed by analysis of variance (ANOVA) followed by Tukey-Kramer test using a statistical program (Proc GLM, SAS Institute, Cary, NC). Normality and homogeneity of variances were checked by Shapiro-Wilk and Hartley tests, respectively. If necessary, logarithmic transformation was applied to data to improve normality. The sources of variation in the model included sex (male and female), age (foal, yearling, adult and elderly), and first-order interactions. All the effects were examined, and the animals were classified as a random effect. In the absence of interaction, only main effect is presented. The data are reported as untransformed least-squares means and the standard error. For all the analyses, a significance level of $5 \%$ $(\mathrm{p}<0.05)$ was used.

\section{RESULTS}

\section{Electrocardiographic parameters}

The physical examinations of the animals revealed normal vital parameters and no signs of cardiac or respiratory disease.

Although it made the measurement of ECG parameters in six leads of the frontal plane and the apex base, is detailed in the tables the DII information, as is the derivation recommended for ECG interpretation, it is the most similar to the axis of heart depolarization. But the other leads must be made to determine the cardiac axis. The BA provides basis for determining the largest complex waves, which facilitates the display, despite being reversed. In this work were expressed both derivations because there was no breed standard.

Table 1 shows the HR and cardiac axis from lead II and HR in the BA for the different age groups and sexes.

A positive bifid P-wave was detected in 5.4\% (11/203) of the animals analysed from lead II, whereas the others presented a single, positive $P$ wave.

Fourteen types of QRS complexes were observed in the ECG examinations of the 203 American Miniature Horses studied from lead II. In foals, the predominant morphology was qR, followed by QS and R. In yearlings, most of the complexes were type Qr, followed by qr and qR. In adults, the predominant morphology types were Qr, QRS, qR and QS. In the elderly horses, the predominant type was Qr, followed by qr and qR. Other types, such as qrs, Rs, rs, qs, rs, $\mathrm{QRS}, \mathrm{QRS}$ and $\mathrm{r}$, were rare in the four analysed age groups. 
One foal, three yearlings, three adults and one elderly horse of the 203 (3.94\%) horses exhibited a depression in their ST segment from lead II. The extent of the unevenness remained between 0.05 and $0.1 \mathrm{mV}$.

\section{Effects of age and sex on electrocardiographic parame- ters}

The predominant cardiac rhythm in both sexes was sinus tachycardia, which was observed in $43.33 \%(26 / 60)$ of males and $62.94 \%$ (90/143) of females. Sinus arrhyth- mia was observed in 35\% (13/60) of males and $11.19 \%$ $(16 / 143)$ of females. Sinus rhythm was present in $21.67 \%$ $(21 / 60)$ of males and $23.08 \%(33 / 143)$ of females. Sinus bradycardia was observed in $2.80 \%$ (4/143) of the females. Two female yearlings (13 months) presented with sinus arrhythmia with a wandering sinus pacemaker. A yearling male (18 months) exhibited sinus arrhythmia and the presence of "sinus arrest".

Table 2 describes the amplitude and Table 3 the duration of the waves, intervals and QRS complexes detected in

Table 1. Heart rate (HR) in beats per minute (bpm) and cardiac electrical axis (degrees) in horses of the American Miniature Horse breed, according to age and sex in leads II and BA

\begin{tabular}{|c|c|c|c|c|c|c|c|}
\hline \multirow[t]{2}{*}{ Leads } & \multirow[t]{2}{*}{ Sex } & \multicolumn{3}{|c|}{ HR (bpm) } & \multicolumn{3}{|c|}{ Axis (degree) } \\
\hline & & Mean \pm SE & $\begin{array}{l}\text { Minimum- } \\
\text { Maximum }\end{array}$ & $\begin{array}{l}\text { Confidence } \\
\text { Interval }\end{array}$ & Mean \pm SE & $\begin{array}{l}\text { Minimum- } \\
\text { Maximum }\end{array}$ & $\begin{array}{l}\text { Confidence } \\
\text { Interval }\end{array}$ \\
\hline \multirow[t]{9}{*}{ II } & Female & $67.3 \pm 1.9$ & $25-121$ & $59.4-64.7$ & $79.8 \pm 12.1$ & $-180-181$ & $51.1-84.7$ \\
\hline & Male & $68.1 \pm 2.4$ & $28-145$ & $61.3-73.8$ & $74.1 \pm 15.3$ & $-158-176$ & $39.8-90.6$ \\
\hline & $\begin{array}{c}\mathrm{p} \text {-value } \\
\text { Age }\end{array}$ & 0.81 & & & 0.7709 & & \\
\hline & Foal & $92.7 \pm 4.0^{c}$ & $56-145$ & $82.7-105.5$ & $128.3 \pm 25.0^{\mathrm{b}}$ & $-150-180$ & 86.4-161.9 \\
\hline & Yearling & $66.1 \pm 2.1^{\mathrm{a}}$ & $25-108$ & $61.7-70.3$ & $54.6 \pm 13.0^{\mathrm{a}}$ & $-169-180$ & $24.3-80.8$ \\
\hline & Adult & $58.0 \pm 2.0^{\mathrm{b}}$ & $28-101$ & $56.5-62.9$ & $56.9 \pm 12.7^{\mathrm{a}}$ & $-173-181$ & $50.6-90.0$ \\
\hline & Elderly & $54.1 \pm 3.8^{\mathrm{b}}$ & $35-85$ & $50.3-59.0$ & $67.8 \pm 23.8^{\mathrm{ab}}$ & $-180-180$ & $20.3-91.3$ \\
\hline & $\mathrm{p}$-value & $<0.0001$ & & & 0.0521 & & \\
\hline & Sex & & & & & & \\
\hline \multirow[t]{8}{*}{$\mathrm{BA}$} & Female & $62.2 \pm 1.7$ & $25-121$ & 59.4-64.7 & - & $-180-181$ & 51.1-84.7 \\
\hline & Male & $64.1 \pm 2.1$ & $28-145$ & $61.3-73.8$ & - & $-158-176$ & $39.8-90.6$ \\
\hline & $\begin{array}{c}\mathrm{p} \text {-value } \\
\text { Age }\end{array}$ & 0.50 & & & & & \\
\hline & Foal & $80.0 \pm 3.5^{c}$ & $56-145$ & $82.7-105.5$ & - & $-150-180$ & $86.4-161.9$ \\
\hline & Yearling & $62.4 \pm 1.8^{\mathrm{a}}$ & $25-108$ & $61.7-70.3$ & - & $-169-180$ & $24.3-80.8$ \\
\hline & Adult & $56.7 \pm 1.7^{\mathrm{b}}$ & $28-101$ & $56.5-62.9$ & - & $-173-181$ & $50.6-90.0$ \\
\hline & Elderly & $53.3 \pm 3.4^{\mathrm{b}}$ & $35-85$ & $50.3-59.0$ & - & $-150-180$ & 20.3-91.3 \\
\hline & p-value & $<0.0001$ & & & - & & \\
\hline
\end{tabular}

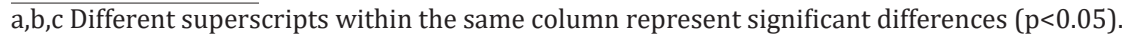

Table 2. Amplitude (millivolts) of the waves ( $\mathrm{P}$ and $\mathrm{T}$ ) of the electrocardiographic exams of horses of the American Miniature Horse breed, according to age and sex in leads II and BA

\begin{tabular}{|c|c|c|c|c|c|c|c|}
\hline \multirow[t]{2}{*}{ Leads } & \multirow[t]{2}{*}{ Sex } & \multicolumn{3}{|c|}{$\mathrm{P}(\mathrm{mV})$} & \multicolumn{3}{|c|}{$\mathrm{T}(\mathrm{mV})$} \\
\hline & & Mean \pm SE & $\begin{array}{l}\text { Minimum- } \\
\text { Maximum }\end{array}$ & $\begin{array}{c}\text { Confidence } \\
\text { Interval }\end{array}$ & Mean \pm SE & $\begin{array}{l}\text { Minimum- } \\
\text { Maximum }\end{array}$ & $\begin{array}{l}\text { Confidence } \\
\text { Interval }\end{array}$ \\
\hline \multirow[t]{9}{*}{ II } & Female & $0.166 \pm 0.005^{\mathrm{a}}$ & $0.09-0.28$ & $0.16-0.17$ & $-0.683 \pm 0.36$ & $-42.00-0.51$ & $-1.17-(-0.02)$ \\
\hline & Male & $0.198 \pm 0.006^{\mathrm{b}}$ & $0.11-0.38$ & $0.17-0.20$ & $-0.245 \pm 0.46$ & $-1.06-0.98$ & $-0.40-(-0.18)$ \\
\hline & $\begin{array}{l}\text { p-value } \\
\text { Age }\end{array}$ & 0.0002 & & & 0.45 & & \\
\hline & Foal & $0.167 \pm 0.010^{\mathrm{a}}$ & $0.10-0.26$ & $0.15-0.20$ & $-0.404 \pm 0.75$ & $-0.77-0.38$ & $-0.61-(-0.21)$ \\
\hline & Yearling & $0.175 \pm 0.005^{\mathrm{a}}$ & $0.09-0.28$ & $0.16-0.18$ & $-0.335 \pm 0.39$ & $-1.18-0.57$ & $-0.43-(-0$ \\
\hline & Adult & $0.175 \pm 0.005^{\mathrm{a}}$ & $0.09-0.27$ & $0.16-0.17$ & $-0.278 \pm 0.38$ & $-1.05-0.98$ & $-0.36-(-0.21)$ \\
\hline & Elderly & $0.211 \pm 0.010^{\mathrm{b}}$ & $0.12-0.38$ & $0.17-0.21$ & $-0.838 \pm 0.72$ & $-42.0-0.52$ & $-3.94-1.06$ \\
\hline & $\mathrm{p}$-value & 0.0124 & & & 0.92 & & \\
\hline & Sex & & & & & & \\
\hline \multirow[t]{8}{*}{ BA } & Female & $0.241 \pm 0.007^{\mathrm{a}}$ & $0.12-0.45$ & $0.23-0.25$ & $0.223 \pm 0.06^{\mathrm{a}}$ & $-1.06-1.20$ & $0.18-0.33$ \\
\hline & Male & $0.276 \pm 0.009^{b}$ & $0.13-0.48$ & $0.24-0.28$ & $-0.236 \pm 0.08^{b}$ & $-1.45-1.27$ & $-0.39-(-0.04)$ \\
\hline & $\begin{array}{l}\text { p-value } \\
\text { Age }\end{array}$ & & & & $<00001$ & & \\
\hline & Foal & $0.230 \pm 0.015^{\mathrm{a}}$ & $0.17-0.31$ & $0.21-0.25$ & $-0.031 \pm 0.137$ & $-1.06-0.89$ & $-0.40-0.26$ \\
\hline & Yearling & $0.246 \pm 0.008^{a}$ & $0.12-0.42$ & $0.23-0.26$ & $-0.038 \pm 0.071$ & $-1.18-1.27$ & $-0.16-0.19$ \\
\hline & Adult & $0.262 \pm 0.007^{\mathrm{a}}$ & $0.15-0.45$ & $0.24-0.27$ & $-0.072 \pm 0.067$ & $-1.45-1.02$ & $0.08-0.31$ \\
\hline & Elderly & $0.295 \pm 0.014^{b}$ & $0.15-0.48$ & $0.25-0.30$ & $-0.029 \pm 0.130$ & $-0.82-0.81$ & $0.05-0.34$ \\
\hline & p-value & 0.0083 & & & 0.68 & & \\
\hline
\end{tabular}

$\bar{a}$ b,c Different superscripts within the same column represent significant differences $(p<0.05)$. 
the ECG assessments from lead II and the BA of the equines of the American Miniature Horse breed according to sex and age (foal, yearling, adult and elderly).

For the interaction of sex in each age group and its effect on ECG parameters, significant differences were observed in the PR and QT intervals and the R-wave amplitude from lead II. In the BA, there were significant differences in the amplitudes of the $\mathrm{R}$ and $\mathrm{S}$ waves.

The PR interval from lead II was higher in the female yearlings than the male yearlings $(p=0.0194)$ and male foals $(p<0.0001)$. In the females, the PR interval was similar for all age groups. The PR interval was higher in the adult males ( $p=0.0403)$ and elderly males $(p=0.0021)$ than in the yearling males. The PR interval was higher in the yearling males $(p=0.0085)$ and adult males $(p<0.0001)$ than the foal males. The PR interval values were lower in the yearling males than the adult females $(p=0.0264)$ and females overall $(p=0.0014)$. The PR interval in the adult females was higher than that of the foal males $(p<0.0001)$ and lower than that of the elderly males $(\mathrm{p}=0.0319)$. The PR interval was lower in the foal males than the elderly females $(p<0.0001)$ and foal females $(p=0.0454)$, which had lower values than the elderly males.

The elderly males had higher values of the R-wave amplitude than the foal males $(\mathrm{p}=0.0047)$ and females $(p=0.0006)$, yearling males $(p<0.0001)$ and females $(p<0.0001)$, adult males $(p=0.0006)$ and females $(p<0.0001)$, and elderly females $(p<0.0001)$. The elderly females had lower values than the adult males $(p=0.0205)$ and foals $(\mathrm{p}=0.0115)$.

The QT interval of the female yearlings was lower than that of the adult males $(\mathrm{p}=0.0189)$, elderly males $(p=0.0174)$ and elderly females $(p=0.0316)$. The QT interval of the foal females was higher than that of the foal males $(\mathrm{p}=0.0469)$ and lower than that of the yearling females $(p=0.0232)$, adult females $(p=0.0080)$, adult males $(p=0.0004)$, elderly females $(p=0.0007)$ and elderly males $(\mathrm{p}=0.0005)$. The male foals had lower QT intervals than the yearling females $(p<0.0001)$ and males $(p<0.0001)$, adult females $(p<0.0001)$ and males $(p<0.0001)$, and elderly females $(\mathrm{p}<0.0001)$ and males $(\mathrm{p}<0.0001)$. The yearling males had lower QT intervals than the adult males $(\mathrm{p}=0.0011)$ and elderly females $(p=0.0016)$ and males $(p=0.0027)$. The QT intervals of the adult females were higher than those of the yearling males $(p=0.0424)$ and lower than those of the adult males ( $p=0.0343)$ and elderly males $(p=0.0302)$.

From the BA lead, the R-wave amplitude was greater in the elderly males than in the yearling females $(p=0.0013)$ and males $(p=0.0101)$, adult females $(p=0.0023)$, elderly females ( $p=0.0018)$ and foal males $(p=0.0047)$. The adult males had higher R-wave amplitudes than the yearling females ( $p=0.0150)$, adult males ( $p=0.0281)$ and elderly females ( $p=0.0235)$. The amplitude of the $S$ wave was lower in the adult females than the yearling females $(p=0.0404)$ and males $(\mathrm{p}=0.0272)$, adult males ( $\mathrm{p}=0.0447)$, elderly males $(p=0.0073)$ and foal females $(p=0.0297)$. The elderly males exhibited higher amplitudes of the $S$ wave compared to the foal females $(p=0.0256)$ and males $(p=0.0086)$, which had lower values than the foal females $(p=0.0303)$.

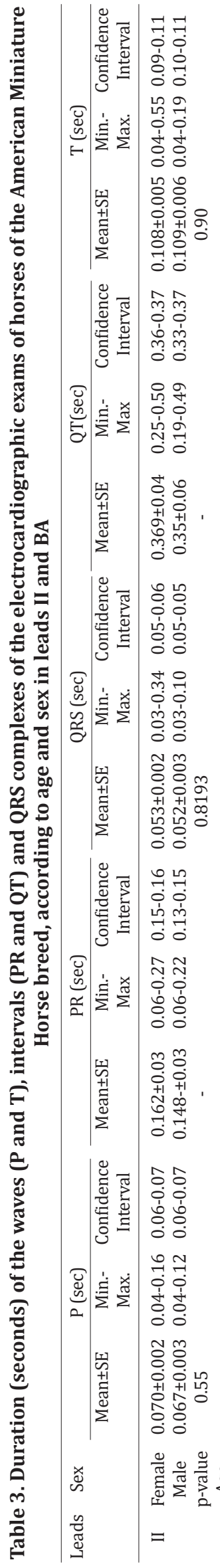

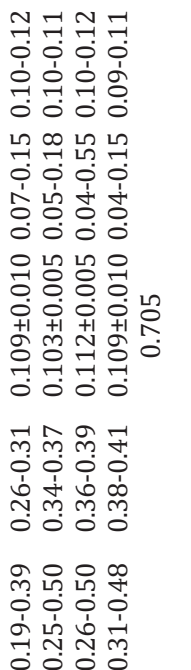

ㄱำ

o

근

Na HNa

굴다.

국그극

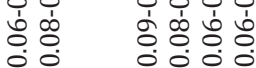

ก็

늉 ㄱํㅇ ㄴํㅇ ᄂ ㄴㅇ

+1

공

궁ํㅇ

워워

$\begin{array}{ll}0 & 0 \\ 0 & 0 \\ m & 1 \\ \text { m. } & 0\end{array}$

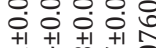

걱 원

०००००००

m

i

ปิ่

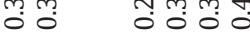

ก กี ติ๊ กี

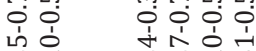

$\circ \circ 00$

००००

oิ

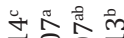

$\begin{array}{lll}0 & 0 \\ 0 & 0 & 0 \\ +1 & +1 & \infty \\ 0\end{array}$

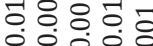

辛市

mָ

กั

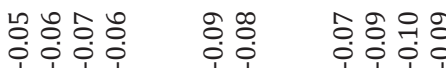

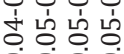

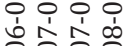

全全

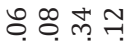

i 윙

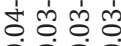

든

둥ํㅇ

เ่ํํํำ

ㅇํㅇ용용

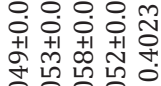

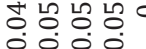

흑득

눈

궁궁궁 궁

승소근

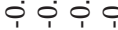

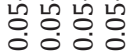

๖ำ

i

송

it +1 i

mo 1 +1

०० 0.000

극

웅

넥 $\infty \approx$

i

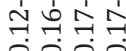

ิำกัก

0. 이우

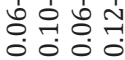

덩 훙

오뉸ㄱ

ำ ำ

i⿱

ơ

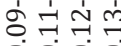

$\circ 0$

ఇัे

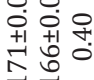

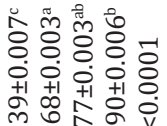

둥궁

궁궁 궁둥

농유용

串

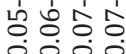

승ㅇㅇㅇㅇㅇ

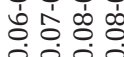

앙궁군궁

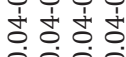

옹.

$0-1$ N

국ำ

궁궁 궁 궁

เ่่

ఫั่

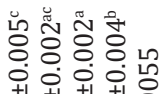

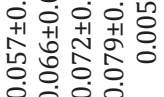

동ํㅇ

웅요

ஸึ ป็

ขㅇㅇㅇㅇㅇ

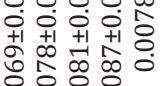

品

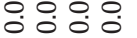

bo 0

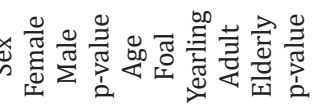

๘ 


\section{DISCUSSION}

The HR variation among the age groups was similar to that described in studies of ponies, which are smaller than horses but have a conformation similar to that of American Miniature Horses. In the ECG of 52 adult female ponies, the mean HR was $43.6 \pm 1.2 \mathrm{bpm}$ in the 12 leads examined (Buss et al. 1975); however, the values in this study for adult and elderly animals were higher, ranging from $58.0 \pm 2.0$ and $54.1 \pm 3.8 \mathrm{bpm}$, respectively. This difference is most likely due to the larger size of ponies compared to American Miniature Horses. No significant differences were observed between the HR of ponies younger or older than 15 years (Rezakhani et al. 2010). The average HR obtained by those authors was lower than that observed in this study, most likely because of the difference in the number of elderly animals evaluated and the larger size of the ponies compared to the American Miniature Horse.

A decrease in HR with increased age has been observed in various horse breeds (Fernandes et al. 2004, Diniz et al. 2008, Palma et al. 2013) because metabolic rate decreases with corporal growth. Thus, energy metabolism is higher in smaller animals and generates an increase in the relative need for oxygen and blood flow to compensate for higher metabolic rates (Ferasin et al. 2010, Schwarzwald et al. 2012). In addition, other factors influence the increased acceleration of metabolism of young animals, including thyroid hormones and cortisol levels (Valentini \& Parati 2009, Lamb et al. 2010). In one study of pony foals from birth until 90 days of age (Lombard et al. 1984), the HR values were similar to those observed in this study, which included foals up to 10 months.

The cardiac axis of the American Miniature Horse differed from the axis of other breeds described in the literature. In Thoroughbred foals, the cardiac axis was shifted to the left and averaged $16 \pm 67^{\circ}$ (Fernandes et al. 2004), whereas in this study, animals of identical ages exhibited cardiac axis shifts to the right that averaged $128.3 \pm 25^{\circ}$. The significant differences in variations of the axis between the age groups in this study reflect a change in the size and position of the heart in the chest during the growth and physical maturation of the animal. In contrast to American Miniature Horses, foals up to two months of age exhibited predominantly negative values on the cardiac axis (Ayala et al. 1998).

Numerous researchers have described the susceptibility of horses to heart rate variations (White and Rhode 1974, Fregin 1982, McGuirk \& Muir 1985, Miller 1987). Many changes have been detected regardless of illness or functional heart impairment; these changes are attributed to the high number of variations in the vagal tone at rest and are considered benign or physiological (McGuirk \& Muir 1985, Miller 1987, Vicenzi et al. 2000a). Pathological conditions such as atrial fibrillation, third-degree atrioventricular block (AVB) and atrial and ventricular (Hilwig 1977) extrasystoles should be differentiated; however, these conditions were not observed in this study of 203 American Miniature Horses nor in 52 pony mares in a previous study (Buss et al. 1975).

Cardiac arrhythmias attributed to the vagal tone (sinus arrhythmia, sinoatrial block, "sinus arrest," sinus bradycardia, migratory pacemaker, and first and second-degree atrioventricular blocks) are observed in healthy horses (McGuirk \& Muir 1985, Robertson 1990). In this study, one occurrence of "sinus arrest" and two occurrences of a migratory pacemaker were observed.

The predominant rhythm in this study was sinus tachycardia, possibly due to the restlessness of the animals during examination. In a previous study of ponies, arrhythmias with a regular rhythm were detected with a Holter monitor (24 hours) in 3 of 24 animals (Rezakhani et al. 2010). In the remaining 21 animals, the authors observed six types of arrhythmias, with sinus arrhythmia and second-degree atrioventricular block being the most common. In one animal of the group that was older than 15 years, a premature ventricular complex (PVC) was detected. In this study, no PVC or other pathological arrhythmias were observed in any of the evaluated animals.

The $\mathrm{P}$ wave in horses has a generally variable morphology that hampers its standardisation because it can be influenced by breed, sex and age (Illera et al. 1987, Melchert et al. 2012). In Andaluz horses, different morphologies of $\mathrm{P}$, including bifid $\mathrm{P}$, single $\mathrm{P}$ and biphasic $\mathrm{P}$, were observed (Ayala et al. 1998). In a previous study, the occurrence of bifid and positive $\mathrm{P}$ waves was described in $68.3 \%$ of Mangalarga Marchador horses, whereas the occurrence of the biphasic P wave was 25\% to 6.7\% (Diniz et al. 2008). Similarly, the authors reported that the biphasic P-wave morphology was the most frequent and occurred in 58.3\% of the evaluated animals (Melchert et al. 2012). In this study, a single and positive $\mathrm{P}$ wave occurred in $94.6 \%(192 / 203)$ of the animals. In one study of ponies, a bifid P wave occurred in approximately 50\% of the animals from the 12 leads that were studied (Buss et al. 1975). In the present study, the presence of single $\mathrm{P}$ waves was likely the result of the higher HRs observed in these animals.

The QRS duration from lead II did not differ between the age groups in this study. These results are not consistent with previous observations in Quarter Horses in which animals older than 10 years had higher QRS durations than younger animals (Mantovani et al. 2013).

In equine medicine, unevenness of the ST segment might indicate myocardial hypoxia or changes in the levels of potassium and blood pH (Babusci \& López 2006). Unevenness of the ST segment above $0.3 \mathrm{mV}$ could be indicative of shock, endotoxemia, abdominal pain, or electrolytic disorders (White \& Rhode 1974, Diniz et al. 2011, Dumont et al. 2011). In this work, a limited number of animals (3.94\%) exhibited an uneven segment that did not exceed $0.1 \mathrm{mV}$.

The conformation of the $\mathrm{T}$ wave might differ between horses at rest, even with spontaneous tracing changes. However, this finding was not observed in other studies (Patteson 1996, Sheard 1998). Knowledge of T-wave morphology in horses is important when monitoring electrolytic and ischemic disorders in which hypoxia and myocardial infarction occur and when monitoring subjects under anaesthesia (Diniz et al. 2008).

In this study, differences in the P-wave durations were 
observed from lead II between the age groups; however, no differences in T waves were observed. In a study of 150 Mangalarga horses, the morphology, duration and amplitude of the waves, intervals and segments were influenced by age, breed and sex, and the $\mathrm{P}$ and $\mathrm{T}$ waves were influenced by age (Vicenzi et al. 2000b).

An ECG profile of 60 Mangalarga Marchador horses (39 females and 21 males) ranging in age from 1 to 28 years (Diniz et al. 2008) revealed an increase in the P-wave amplitude with animal growth similar to that observed in this study of the American Miniature Horse. The duration of the QRS complex was also higher in males than in females (Diniz et al. 2008), which was not observed in the American Miniature Horse.

The findings of this study based on the BA lead are consistent with a previous examination of the cardiac parameters of 12 pony foals (Lombard et al. 1984), which are similar in size to American Miniature Horse foals, and with the values of the PR and QT intervals, which were lower in the foals than in the other age groups. These findings suggest that the ventricular conduction velocity is lower in foals than in adult animals because of their smaller heart size.

\section{CONCLUSIONS}

This study allowed us to establish the ECG examination parameter benchmarks for the American Miniature Horse in six leads of the frontal plane and BA.

Heart rates (HR) decreased with increasing age and were higher in males than in females.

Sinus tachycardia followed by sinus arrhythmia was dominant in both sexes. The cardiac axis was higher in males and ranged between $120^{\circ}$ and $150^{\circ}$ for foals, $30^{\circ}$ and $60^{\circ}$ for yearlings and adults, and $60^{\circ}$ and $90^{\circ}$ for the elderly.

The $\mathrm{P}$ wave was bifid in several animals. The P-wave amplitude and T-wave duration from lead II and BA were larger in males than in females.

The majority of the animals exhibited ST segment depression and a negative T-wave.

The most common QRS complex morphology was Qr.

Differences were observed between the electrocardiographic tracings of males and females, and age influenced the ECG parameters.

Although the American Miniature Horse is similar in size to pony breeds, the results revealed differences that indicate the unique features of this breed.

Acknowledgements.- The authors thank the owners of the following farms for their assistance: São Benedito/Avaré-SP (José Bastos Cruz Sobrinho), Cabanha Guguiná/Lençóis Paulista-SP (Luís Santana Zillo), Jequitibá/Cerqueira César-SP (Marcelo Assumpção Serra), and Água Azul/Dois Córregos-SP (José Eden Matosinho).

Conflict of interest statement. - The authors have no competing interests.

\section{REFERENCES}

Associação Brasileira dos Criadores de Mini-Horse 2013. Características da raça. [Internet]. Cited Dec. 20, 2013. Available from <http://www. ponei.com.br/arquivos_PDF/Historico_Ficha_Tecnica.pdf>

Ayala I., Gutierrez-Panizo C., Benedito J.L., Prieto F. \& Montes A. 2000. Morphology and amplitude values of the electrocardiogram of Spanish-bred horses of different ages in the Dubois leads system. Vet. Res. 31:347354.

Ayala I., Montes A., Benedito J.L., Castillo C., Hernández J., Gutierrez C. \& García-Partida P. 1998. Modifications of the form and amplitude of the electrocardiographic QRS complex during growth in the Spanish-bred horse. Zentralbl. Veterinärmed. A. 45:309-317.

Ayala I., Montes A., Bernal L.J., Sandoval J.A. \& Gutierrez C. 1995. Electrocardiographic values in Spanish-bred horses of different ages. Aust. Vet. J. 72:225-226.

Babusci M. \& López E. 2006. Sistema cardiovascular, p.61-85. In: Boffi F.M. (Ed.), Fisiologia del Ejercicio Equino. Inter-Médica, Buenos Aires.

Bello C.A.O., Dumont C.B.S., Souza T.C., Palma J.M., Lima E.M.M., Godoy R.F., Neto G.B.P. \& Meryonne M. 2012. Avaliação eletrocardiográfica de equinos após exercício de polo (baixo handicap). Pesq. Vet. Bras. 32:47-52.

Buss D.D., Rwalings C.A. \& Bisgard G.E. 1975. The normal electrocardiogram of the domestic pony. J. Electrocardiology 8:167-172.

Diniz M.P., Muzzi R.A.L., Muzzi L.A.L. \& Alves G.E.S. 2008. Estudo eletrocardiográfico de equinos da raça Mangalarga Marchador. Arq. Bras. Med. Vet. Zootec. 60:536-542.

Diniz M., Michima L. \& Fernandes W. 2011. Estudo eletrocardiográfico de equinos de Salto sadios. Pesq. Vet. Bras. 31:355-361.

Dumont C.B.S., Leite C.R., Moraes J.M., Alves R.O., Godoy R.F. \& Lima E.M.M. 2010. Parâmetros eletrocardiográficos de equinos Puro Sangue Árabe submetidos a exercício prolongado de enduro. Ciência Rural 40:19661973.

Dumont C.B.S., Moraes J.M., Leite C.R., Alves R.O., Moreira M., Moscardini A.R.C., Godoy R.F. \& Lima E.M.M. 2011. Parâmetros eletrocardiográficos de equinos desclassificados por exaustão em competições de enduro. Arq. Bras. Med. Vet. Zootec. 63:20-27.

Ferasin L., Ferasin H. \& Little C. J. 2010. Lack of correlation between canine heart rate and body size in veterinary clinical practice. J. Small Anim. Pract. 51:412-418.

Fernandes W.R., Larsson M.H.M.A., Alves A.L.G., Fantoni D.T. \& Belli C.B. 2004. Características eletrocardiográficas em equinos clinicamente normais da raça Puro Sangue Inglês. Arq. Bras. Med. Vet. Zootec. 56:143149.

Fregin G.F. 1982. The equine electrocardiogram with standardized body and limb positions. Cornell Vet. 72:304-324.

Hilwig R.W. 1977. Cardiac arrhythmias in the horse. J. Am. Vet. Med. Assoc. 170:153-163.

Illera J.C., Illera M. \& Hamlin R.L. 1987. Unipolar thoracic electrocardiography that induces QRS complexes of relative uniformity from male horses. Am. J. Vet. Res. 48:1700-1702.

Lamb A.P., Meurs K.M. \& Hamlin R.L. 2010. Correlation of heart rate to body weight in apparently normal dogs. J. Vet. Cardiology 12:107-110.

Lessa D., Escodro P. \& Notomi M. 2012. Considerações sobre o uso da eletrocardiografia e sua interpretação em equinos. Revta Bras. Med. Equina 42:4-12.

Lombard C.W., Evans M., Martin L. \& Tehrani J. 1984. Blood pressure, electrocardiogram and echocardiogram measurements in the growing pony foal. Equine Vet. J. 16:342-347.

Mantovani M.M., Tsuruta S.A., Muzzi R.A.L., Machado T., Pádua M.F.S., Coimbra C., Muzzi L.A.L. \& Jacomini J.0. 2013. Electrocardiographic study in the American Quarter Horse breed. Arq. Bras. Med. Vet. Zootec. 65:1389-1393.

McGuirk S.M. \& Muir W.W. 1985. Diagnosis and treatment of cardiac arrhythmias. Vet. Clin. North Am., Equine Pract. 1:353-370.

Melchert A., Laposy C.B., Guasi V.H.B., Valle H.F.D. \& Santos G.C. 2012. Eletrocardiografia computadorizada em cavalos Puro Sangue Lusitano submetidos a exercício físico. Arq. Bras. Med. Vet. Zootec. 64:547-554.

Miller M.S. 1987. A cardiac arrhythmia in the horse: is the ECG normal? J. Equine Vet. Sci. 7:285-289.

Palma J., Caniello N., Souza T., Bello C., Dumont C. \& Lima E. 2013. Avaliação eletrocardiográfica em potros quarto de Milha de diferentes idades. Biosciences 29:174-178. 
Patteson M. 1996. Equine Cardiology. Blackwell Publishing House Science, Oxford.

Pedersen P.J., Kanters J.K., Buhl R. \& Klaerke D.A. 2013. Normal electrocardiographic QT interval in race-fit standardbred horses at rest and its rate dependence during exercise. J. Vet. Cardiology 15:23-31.

Rezakhani A., Pirie R. \& Blissitt K. 2010. Effects of age on the prevalence of cardiac dysrhythmias in ponies. Iranian J. Vet. Res. 11:200-205.

Robertson S. A. 1990. Practical use of ECG in the horse. In Practice 12:59-67.

Robertson S. 1992. Electrocardiography for the equine practitioner. Vet. Annual 32:192-200.

Schwarzwald C.C., Kedo M., Birkmann K. \& Hamlin R.L. 2012. Relationship of heart rate and electrocardiographic time intervals to body mass in horses and ponies. J. Vet. Cardiol. 14:343-350.

Sheard P. 1998. Cardiovascular system, p.295-438. In: Colahan P.T. (Ed.), Equine Medicine and Surgery. Mosby, St Louis.
Valentini M. \& Parati G. 2009. Variables influencing heart rate. Progress Cardiovasc. Dis. 52:11-19.

Vicenzi R., Larsson M. \& Fernandes W. 2000a. Parâmetros eletrocardiográficos de equinos clinicamente normais da raça Mangalarga. I. Frequência e ritmo cardíaco. Revta Bras. Med. Vet. 22:71-73.

Vicenzi R., Larsson M. \& Fernandes W. 2000b. Parâmetros eletrocardiográficos de equinos clinicamente normais da raça Mangalarga. III. Amplitude e duração dos complexos e intervalos. Revta Bras. Med. Vet. 22:194198.

White N.A. \& Rhode E.A. 1974. Correlation of electrocardiographic findings to clinical disease in the horse. J. Am. Vet. Med. Assoc. 164:46-56.

Yonezawa L., Machado L., Silveira V., Watanabe M., Saito M., Kitamura S. \& Kohayagawa A. 2009. Exame eletrocardiográfico em equinos da raça puro sangue árabe submetidos ao exercício em esteira de alta velocidade e à suplementação com vitamin E. Arch. Vet. Sci. 14:34-142. 